\section{Implantation of Ureters.}

New York Citr, April 11, 1901.

To the Editor:-In view of the fact that the patient on whom I operated for implantation of the ureters into the rectum by a new method, as described in the American Journal of the Medical Sciences, Vol. clv., pp. 270-276, is still living and enjoying the best of health at the end of $4 \frac{1}{2}$ years-not $3 \frac{1}{2}$ years, as stated by Dr. Peterson. I wish to protest against paragraph 3 , in the General Conclusions at the end of his article on "Ureteral Anastomosis" (TuE Jorrnal, March 23, p. 814 ), in which he says: "All efforts to prevent ascending renal infection in animals or in man where the ureter has been implanted without its vesical orifice have proved futile." In order to support the contention that the "operation is unjustifiable" (paragraph 5, General Conclusions), he endeavors to assume that, in my case, "the kidneys have been infected, but that the infection has been overcome with resulting contracted kidneys." This assumption in the absence of the slightest suspicion that such has actually occurred in the case, would seem to be in a great measure gratuitous, if not absolutely unwarranted, even though "experimental work would lead us" to such a conclusion.

Further, I wish to call attention to the alleged foundation for thus discounting, and even practically ignoring, the result in this case. It would appear, by a paragraph on the same page, that Dr. Peterson performed the operation on a dog, implanting one ureter, and killed the $\operatorname{dog}$ at the end of twentyseven days. At the autopsy the kidney corresponding to the implanted ureter was found to be "decidedly smaller than the other and showed evidences of ascending infection. No bacteriologic or microscopic report on the specimen has yet been made" (italics mine).

Beyond ealling Dr. Peterson's attention to the fact that the mucous valve formation is neither the only nor the most important feature of the operation in question, and that therefore its disappcarance in the case of the dog need not necessarily militate against the procedure, it is scarcely necessary for me to waste your space by further comment. Yours very truly,

G. R. Fowler, M.D.

\section{Immunity Against Zymotic Diseases.}

Topeka, Kans., April 18, 1901.

To the Editor:--I have read, with appreciation, the article on "Immunity Against Zymotic Diseases," by Dr. J. W. Class, published in Tre Journal of April 13, and have been much impressed by the author's lucid exposition of what is generally considered a perplexing theme.

The rather unique theory advanced by the author particu. larly attracted my notice. because its essential features had all been presented and elaboratel in a paper of similar import, read Feb. 18, 1901, before the Medical Science Club of Topeka, by 1)r. O. P. Davis, of this city, the criginal of which is in my keeping as secretary of that organization. In this paper, Dr. Davis, after canvassing the various theories of immunity, and pointing out their insuficiency, arrives by a process of deductive reasoning at what secms to be a new and plausible theory embracing all that Dr. Class sets forth, and more. The following main propositions were developed:

1. Acquired immunity is due to the continued presence in the body of the specific microbe of the given disease, in a form sufficiently attenuated to be tolerated by the host, and yet sufficiently active to stimulate the production of an antitoxin.

2. Germs may undergo attenuation outside, as well as within, the body, and entering the body, thus attenuated, may confer protection without typical infection.

3. Juring the whole time that this immunity continues the attenuated germs continue to reside in the protected body.

4. Such germs as will not undergo a stable attenuation, but tend to revert to the virulent type, will not confer permanent immunity by their presence in the body, but bring about either an immunity that is transient, or an increased susceptibility with subscquent reinfection, or both.
All these propositions were amply developed in Dr. Davis's paper, and though Dr. Davis set forth no special claim to originality on this subject, yet it seems that he has the priority over Dr. Class at least, in the enunciation of what appears to be a well-sustained theory. Fery truly,

Corban E. Judd, M.D.

\section{Anesthesia of Ear Drum.}

\section{Memphis, Tenn., April 3, 1901.}

To the Editor:-In Dr. Henry Gradle's recent article on "Purulent Otitis, Its Treatment and Prevention by the Family Physician" (The Jocrnal, March 30), in speaking of paracentesis of the drum membrane. he says that it is a painful procedure and the pain is not lessened by any of the local anestheties. I would like to mention a combination of local anesthetics which I have found to act admirably in producing an anesthesia of the drum, permitting painless paracentesis. The mixture is equal parts of cocain, carbolic acid and menthol. It is attributed, I believe, to Bonain (Rev. Heb. de Lar., June 17,1899 ), and I claim no originality in connection with it. I have used it many times this winter with invariable satisfaction. After cleansing and drying the canal, I have applied this mixture with a cotton-tippel applicator directly to that portion of the drum which I wished to incise. In a moment the surface becomes white, and this is convenient in that it be comes easier to confine your incision to anesthetized parts. While I have used it mostly in adults, I have also tried it in children, and in them it is equally sucesseful if you can allay their fears over the prospect of being cut. In one woman I did double paracentesis at one sitting without pain, and later in the progress of the case it became advisable to enlarge the too rapidly closing incision. This was done under the same mixture, and again without pain. I would like to urge on my colleagues in otology the use of this mixture, with which I am sure they will be pleased. Another popular mixture for the same purpose was suggested by A. A. Gray, in The Lancet of April 21, 1900, and is composed of cocain, alcohol and analin oil, in the proportion of 5 per cent of the alkaloid in equal parts of the other two ingredients, but I have had no experience with it. Very truly,

E. C. ElLetT, M.D.

\section{Original Papers Used for Advertising.}

Phitadelphia, April 16, 1901.

To the Editor:--In reference to the communication from $\mathrm{Dr}$. Harvey, on page 1058 of The Jourxal of April 13, I would say that this matter did come to my ears verv shortly before I saw his letter. I at once wrote to the manufacturers, who have so used my article, to stop all and every use made thereof, which they very promptly promised to do. That I never knew anything about the uses thus made, is a sufficient answer to the question at issue. If this is not satisfactory, I respectfully refer to the manufacturess, who have expressed great regret for using my paper at all, which was a sufficient apology to me, and I hope satisfactory to Dr. Harvey also Yours, Edws Rosenthal, M.D.,

Former Chairman of the Section on Diseases of Children.

\section{Life Expectancy in Medical Men.}

\section{Burlington, N. C., April 11, 1901.}

To the Editor:- Having seen it stated that medical men are shorter lived than those of other professions and trades, I have collected from the obituary notices in THE Jouksal in suecession as the deaths occur, the ages of 510 physicians, in the United States, Canada, and Europe. These statistics include deaths from accident and suicide, as well as those from disease. I find the average age to be 58 years and 9 months, not such a bad showing for the longevity of the physician after all, especially as the cases from accident and suicide, as well as casualties in the army service, are included. Yours truly, 